\title{
Exploitation-exploration balance and its performance outcomes: A study of FDI portfolio decisions of new multinationals
}

\author{
Piotr Trąpczyński, Tilo Halaszovich
}

\begin{abstract}
A B S T R A C T
Objective: The objective of the article is to explore how new multinationals construct their FDI location portfolios and what the performance outcomes of these decisions are.

Research Design \& Methods: Building our conceptual framework on the organisational learning theory, we conduct regression analysis based on data from 394 subsidiaries of new Polish multinationals.

Findings: We find that the possession of superior capabilities by new multinationals enhances their ability to reap benefits from investing in more advanced markets in their portfolios and hence engaging in higher ambidexterity, i.e. the combination of exploration and exploitation. This effect is further reinforced by experience with foreign investment.

Implications \& Recommendations: Investment in more advanced economies as compared to the home country entails the possession of higher-order capabilities, as it requires higher ambidexterity from new multinationals.

Contribution \& Value Added: A lot of existing IB research focused on discrete location choices in internationalisation, remaining oblivious of the broader strategic logic. Moreover, it has been assumed that - particularly for new multinationals from emerging countries - entries into advanced host countries are related to exploration rather than exploitation, whereby the latter is the domain of similar or less developed markets.

\begin{tabular}{lll}
\hline $\begin{array}{l}\text { Article type: } \\
\text { Keywords: }\end{array}$ & $\begin{array}{l}\text { research article } \\
\text { new multinationals; location choices; portfolio perspective; firm capabilities; firm per- } \\
\text { formance; Central and Eastern Europe }\end{array}$ \\
JEL codes: & F23, L25, M16 & \\
\hline \multicolumn{4}{c}{ Received: 29 July 2020 } & Revised: 22 April 2021 & Accepted: 4 May 2021
\end{tabular}
\end{abstract}

\section{Suggested citation:}

Trąpczyński, P., \& Halaszovich, T. (2021). Exploitation-exploration balance and its performance outcomes: A study of FDI portfolio decisions of new multinational. Entrepreneurial Business and Economics Review, 9(4), 115-129. https://doi.org/10.15678/EBER.2021.090408

\section{INTRODUCTION}

New multinationals, i.e. firms from mid-range emerging economies with an often accelerated speed of internationalisation (García-Canal, Guillén, Fernández, \& Puig, 2018; Guillén \& Garcia-Canal, 2009; Hoskisson, Wright, Filatotchev, \& Peng, 2013; Kumar, Singh, Purkayastha, Popli, \& Gaur, 2020; Lee \& Fernando, 2020; Polowczyk, Zaks, \& Trąpczyński, 2021), have emerged on a global scale, therefore challenging existing academic and practitioner wisdom. Their importance has been continually increasing, even though new multinationals are still in general less known internationally for their brands (Ramamurti, 2012; Maciejewski \& Wach, 2019; Barłożewski \& Trąpczyński, 2021b). Because of their relatively weaker intangible resource base, new multinationals have been facing a strategic dilemma to what degree host markets that are more advanced than the domestic market should prevail in their foreign direct investment (FDI) portfolios.

Extant research has suggested that firms that cannot "exploit" their existing firm-specific advantages could potentially "explore" for a new advantage in foreign markets (Banalieva \& Dhanaraj, 
2013; Hernandez \& Guillén, 2018; Ramamurti, 2012; Wu \& Ang, 2020). However, other scholars have cautioned that learning from sophisticated foreign markets is fraught with uncertainty due to liability of foreignness and highly formalised labour and capital markets with which new multinationals have little, if any, experience (Zaheer, 1995; Zahra et al., 2000). Thus, international exploration may not necessarily lead to success (Hennart, 2012). Indeed, there are signals that early successes of earlystage MNEs (multinational enterprises) can lead to cognitive biases and over-optimism (Thomas, Eden, Hitt, \& Miller, 2007). In fact, it has been found that traditional FDI into a developing country can actually create more firm value that strategic asset-seeking FDI into developed countries (Yang, Martins, \& Driffield, 2013). Thus, a vital question arises as to the boundary conditions of new multinationals' location choices and their outcomes.

Quite strikingly, a systematically missing feature of existing research on new multinationals (and MNEs in general) is the treatment of location choices as parts of overall global strategy of the firm rather than merely looking at discrete choices (Kim, Hoskisson, \& Lee, 2015; Głodowska, Pera, \& Wach, 2019). While it has been - quite simplistically - argued that firms choose more advanced countries so as to obtain new assets, and less advanced countries exploit existing ones (Makino, Lau, \& Yeh, 2002; Tsang \& Yip, 2007), few studies have reached beyond discrete location decisions and viewed the learning process of new multinationals as a phenomenon from a location portfolio perspective (Kim, Hoskisson, \& Lee, 2015). While this approach to firm analysis is well known from research on portfolios of strategic alliances (e.g. Asgari et al., 2017), or international equity investments (e.g. Ozmel \& Guler, 2015), it is yet to be applied to the location choices and performance of new multinationals.

Thus, drawing insights from the exploration-exploitation literature (Anand, Mesquita, \& Vassolo, 2009; Gupta, Smith, \& Shalley, 2006; Rivkin \& Siggelkow, 2003; Siggelkow \& Rivkin, 2006; Tsang \& Yip, 2007), we seek to address the aforesaid deficiencies in extant scholarship by exploring the duality of foreign market exploration and exploitation in establishing FDI market portfolios, as most firms do have to engage in both (Miller, Zhao, \& Calantone, 2006), and how FDI market portfolio composition can provide a dynamic way to achieve this. This research question is challenging because to date, the exploration-exploitation literature has limited its analysis to a simplified explanation of how intangible resources affect FDI (Makino, Lau, \& Yeh, 2002), or how the choice of host market affects firm performance (Kim, Hoskisson, \& Lee, 2015), but not both simultaneously. To be best of our knowledge we are the first scholars studying location choices to examine not merely discrete market entry choices, but the prevalence of particular location choices in the overall internationalisation strategy. In doing so, contrary to most studies, we do not look at single decisions to enter a foreign market, but rather at motivations to compose a portfolio of markets of a certain type.

We pursue these objectives based on a sample of new multinationals from a post-transition economy. Due to their early-stage international strategy, managers of new multinationals often insist on establishing overseas operations in the most developed markets like the USA or Western Europe (Khan, 2020). Indeed, a significant part of research on emerging country MNEs has revolved around the still nascent firm capabilities and expansion into more advanced markets as a way of overcoming this weakness (Crescenzi, Pietrobelli, \& Rabellotti, 2015).

\section{LITERATURE REVIEW}

\section{Locational ambidexterity and firm performance}

The perspective of exploitation and exploration has been influential in different subdisciplines of organisation and management (e.g. Lavie \& Rosenkopf, 2006; Rivkin \& Siggelkow, 2003). These two concepts are originally rooted in the area of organisational learning and their distinction has traditionally relied on the type of learning, or rather presence or absence thereof. While the concepts of exploitation and exploration in organisational studies have frequently been applied to the field of innovation (e.g. He \& Wong, 2004; Paliokaite, 2019), particularly, in knowledge-intensive and innovation-absorbing industries (Braja \& Gemzik-Salwach, 2020), their application in the context of international business, particularly geographic expansion of firms, has been much more seldom (Rudawska, Frąckiewicz, \& Wiścicka-Fernando, 2018; Kim, Mahoney, \& Tan, 2015; Makino, Lau, \& Yeh, 2002). As international 
business research has shifted from a predominantly headquarters-focused perspective to more attention to the significance of foreign affiliates (Rugman \& Verbeke, 2001), the issue of explorative rather than merely exploitative FDI has surfaced in a number of studies (Galan et al., 2007).

In reality, international expansion is driven by diverse motivations, which lead to different effects on firm performance (Li, 2007; Verbeke \& Brugman, 2009; Verbeke, Li, \& Goerzen, 2009; Barłożewski \& Trąpczyński, 2021). However, in spite of extant evidence that FDI is driven by bundles of motivations (Demirbag, Tatoglu, \& Glaister, 2007; Hennart, 2012; Cieślik \& Hien Tran, 2019; Cieślik et al., 2019), most studies have focused either on exploitative or explorative FDI, with few attempts at considering these perspectives jointly (Kim, Mahoney, \& Tan, 2015). Meanwhile, scholars have argued that the key to reconciling both perspectives lies in "ambidexterity" (Benner \& Tushman, 2003; March, 1991; Stjepić et al., 2020). Ambidexterity as a mechanism of achieving balance is related to achieving exploitation and exploration synchronously through different loosely connected organisational units or individuals, specialising in one of the aforesaid learning modes (Raisch \& Birkinshaw, 2008). In the context of location choices by MNEs, the network of foreign affiliates can be considered as a system of differentiated subunits with specialised mandates allocated by the parent firm (Rugman \& Verbeke, 2001). Thus, we argue that by constructing geographic portfolios of affiliates, MNEs can seek balance between relying on their experience and exploiting their existing capabilities in less demanding markets than the home country, and upgrading their capabilities by establishing presence in markets that are more challenging. Henceforth, we shall refer to this balance as locational ambidexterity.

As exploitation and exploration cannot ensure sustained performance in isolation, we argue that an excessive focus on explorative FDI can be detrimental to MNE performance insofar as performance, particularly financial, is driven by fundamentals such as market size or cost efficiency (Demirbag, Tatoglu, \& Glaister, 2007). We expect that pursuing more developed markets (vs. home country) in location portfolios with a sole focus on exploration is likely to be challenging, as developed countries necessitate regular product upgrades in order to match the requirements of end users (Hamzaoui \& Merunka, 2006). Conversely, an excessive reliance on exploitation may result in quick performance gains which persuade managers about the legitimacy of following the same strategy, therefore often leading to the so called "success trap" (Gupta, Smith, \& Shalley, 2006). In fact, some new MNEs find it easier to operate in less developed countries (Cuervo-Cazurra \& Genc, 2008). These possibilities are available in inmmature markets considering the current state of their regulation (Bilan et al., 2020; Mishchuk et al., 2020). It is conceivable that significant previous success, as expressed by MNE performance, will lead to exploitation of their advantageous position in markets with lower entry barriers (Del Sol \& Kogan, 2007). A frequent trajectory of new MNEs is to exploit their successful products in markets at different stages of their industry lifecycle (Kim, Mahoney, \& Tan, 2015). However, the sole focus on exploitation may not pay off in the long run (Benner \& Tushman, 2003).

Hence, we propose that the more ambidextrous the international expansion is, the better for the performance of new multinationals. While the focus on less developed markets would typically mean a predominance of exploitation, we simplistically assume that as the composition of foreign market portfolios of new multinationals becomes more skewed towards more developed markets, also the extent of the combination of exploration and exploitation increases (Hennart, 2012). Thus, we posit:

H1: The higher the locational ambidexterity of new multinationals, the higher their performance.

\section{The moderating role of firm capabilities}

While exploration and exploitation are both instrumental for performance, they also compete for limited organisational assets, whereby an organisation has to share the available resources between exploration and exploitation (Levinthal \& March, 1993; Kim, Mahoney, \& Tan, 2015). Yet, whether an organisation is able to reconcile these two learning modes may be contingent upon its knowledge pool or the ability to gain access to new knowledge (Levinthal \& March, 1993). Moreover, entering more developed markets that facilitate exploration, requires overcoming entry barriers in the first place (Hymer, 1976).

We expect that new multinationals with stronger capabilities will be better able to address the challenges of more sophisticated markets than their own country (Chan, Isobe, \& Makino, 2008). Such 
firms are better able to communicate their value propositions to their customers and differentiate from competitors (Kohli \& Jaworski, 1990). They can also more easily develop new products, adapt to the more competitive markets in the developed world, and develop product warranties to assure more experienced customers about the quality of their products. Hence, we argue that the appropriability of new knowledge by new multinationals, while simultaneously exploiting existing capabilities, will be more effective for new multinationals possessing superior capabilities. Thus, we propose:

H2: The effect in $\mathrm{H} 1$ is stronger for new multinationals which possess superior capabilities.

\section{The boundaries of locational ambidexterity: portfolio management experience and portfolio complexity}

Experience in managing FDI portfolios is crucial from the perspective of cross-border learning (Luo \& Tung, 2007). Particularly for new MNEs, learning in foreign markets is not necessarily doomed to succeed (Zahra, Ireland, \& Hitt, 2000; Zaheer, 1995). If new multinationals enter more advanced markets, they are likely to face some difficulties in coping with these countries' formalised labour and capital markets (Chacar, Newburry, \& Vissa, 2010), as well as the reliance on formal written contracts instead of informal arrangements (McMillan \& Woodruff, 2002). Experience of operating through FDI, both in similar and dissimilar markets to the ones being currently entered, may be crucial for both explorative and exploitative FDI and its performance (Trąpczyński \& Banalieva, 2016).

Furthermore, a rising level of locational ambidexterity may in consequence lead to the dispersion of managerial attention. In fact, particularly for early-stage MNEs making their first genuine decisions about the composition of their geographic portfolios, such a dual focus may be challenging (Luo \& Tung, 2007). Previous research has provided evidence for a tendency to rely on established organisational routines established in the course of earlier experience with geographic expansion (Pattnaik, Choe, \& Singh, 2015; Perkins, 2014). Indeed, the ability to successfully engage in exploration in foreign markets is typical of more mature, advanced MNEs rather than the entire population of MNEs (Dunning, Kim, \& Park, 2008). We argue, accordingly, that the experience of managing FDI projects allows new MNEs to allocate better their managerial capabilities and balance different involvements in their locational portfolios more successfully. Therefore, we propose that:

H3: The moderating effect in $\mathrm{H} 2$ is stronger for new multinationals with a higher portfolio management experience.

Figure 1 summarises our conceptual framework.

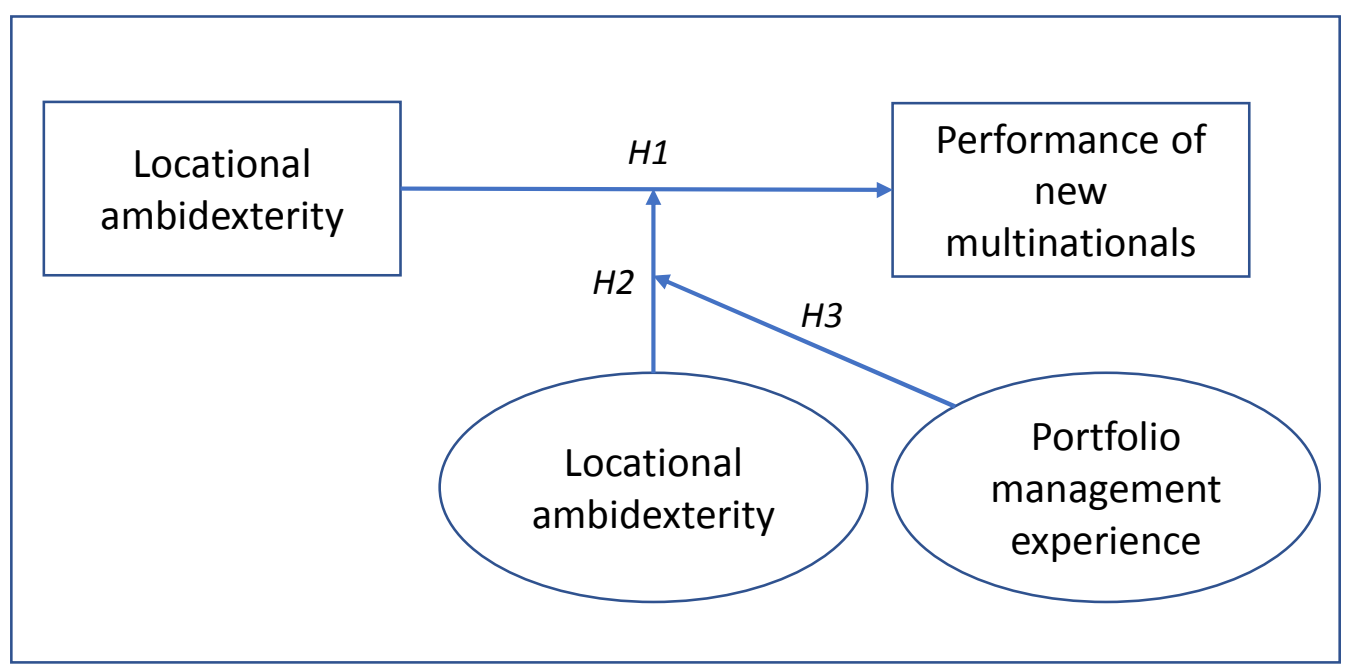

Figure 1. Conceptual framework

Source: own elaboration. 


\section{RESEARCH METHODOLOGY}

\section{Data and sample}

We tested the above hypotheses by using a CATI study of foreign outward investors from Poland (20132014). We shortlisted the Polish firms suitable for our survey from a variety of secondary sources (including the Amadeus, BPR Benchmark Poland, and corporate communications). In order to be included in the database, the companies had to be registered in Poland and hold a minimum of $10 \%$ of shares in a subsidiary located abroad (Padmanabhan \& Cho, 1999). Thus, we obtained a shortlist of 882 Polish firms with actual FDIs in the period under investigation.

A single key informant approach was adopted, by inviting executives directly responsible for the foreign activities of the firm to take part in the CATI study (Sousa, Ruzo, \& Losada, 2010). A sample of 100 complete surveys was obtained, corresponding to an effective response rate of $11.3 \%$, which remains in line with prior research on transition economies (Kriauciunas, Parmigiani, \& Rivera-Santos, 2011). Accordingly, all the firm-level data are survey-based, except for country-level data. The countrylevel institutional data come from the World Bank's World Governance Indicators, World Bank's open Database, Hofstede's cultural database, and Centre d'Etudes Prospectives et d'Informations Internationales (CEPII) database of geographic distance (Mayer \& Zignano, 2005).

\section{Statistical Analysis}

We tested our hypotheses with OLS regression models in Stata/MP 15.1. We estimated OLS regression models because of the cross-sectional structure of our dataset. We started our analysis with a baseline model (Eq. 1). In Eq. 2, we added measures for the economic, institutional and cultural compositions of the MNEs' country portfolios. Next, we tested the interaction between MNE resources and the economic country portfolios (Eq. 3). We estimated the final equation for the full sample as well as for a split of the sample into groups of MNEs with an above (below) average number of FDls. This sub-group analysis aims to test $\mathrm{H} 3$.

$$
\begin{aligned}
& \text { MNE Overall Success }=\text { Constant }+\beta 1 \mathrm{FDI} \text { Experience }+\beta 2 \text { MNE Reputation }+\beta 3 \text { MNE Size }+ \\
& \beta 4 \text { MNE Age }+\beta 5 \text { MNE Capabilities + } \beta 6 \text { Industry } \\
& \text { MNE Overall Success }=\text { Constant }+\beta 1 \text { FDI Experience }+\beta 2 \text { MNE Reputation }+\beta 3 \text { MNE Size }+ \\
& \beta 4 \text { MNE Age }+\beta 5 \text { MNE Capabilities }+\beta 6 \text { Economic Portfolio }+\beta 7 \text { Institutional Portfolio }+\beta 8 \\
& \text { Cultural Portfolio }+\beta 9 \text { Industry }
\end{aligned}
$$

\section{Measures}

\section{Performance}

We captured performance with a subjective measure (see e.g. Brouthers, Brouthers, \& Werner, 2008; Brouthers, Nakos, Hadjimarcou, \& Brouthers, 2009), MNE overall success. Respondents were asked to evaluate on a 5-point Likert scale (1=we are much worse; $2=$ we are worse; $3=$ we are at the same level; $4=$ we are better; and $5=$ we are much better) how they perform relative to their closest rival. The aforementioned scale demonstrates a decent level of reliability, with the Cronbach's Alpha=0.84.

\section{Capabilities}

Respondents were requested to evaluate on a 5 -point Likert scale ( 1 =we are much worse; 5 =we are much better) how the capabilities (market adaptation, new product introduction, marketing, managerial, technological and operational efficiency) of their company compare to those of their closest competitor. Capabilities for each firm were obtained by averaging the Likert scores of all five capabilities. For the analysis, we mean-centred the average scores. The construct showed a value of Cronbach's Alpha of 0.88 . 


\section{FDI Experience}

To capture the experience with FDI of our sample firms, we used the maximum number of years each firm was operating any FDI.

\section{Locational ambidexterity}

We proxied locational ambidexterity with the economic portfolio composition, using GDP per capita as the measure of economic development. To compute the distance between the home country and each of the host countries of the subsidiaries of the sample firms, we applied the Kogut and Singh (1988) formula, which was rooted in order to account for the direction of the distance. The host country scores were summed up to obtain the FDI portfolio composition and divided by the number of countries in the portfolio in order to eliminate outliers. Thus, more positive values of this continuous index indicate that the FDI portfolio of the Polish firm is dominated by countries more advanced than Poland. Conversely, more negative values of the continuous index indicate that the FDI portfolio of the Polish firm is dominated by countries less developed than Poland. To summarise, this variable can be expressed by the following formula:

where:

$$
\operatorname{LocAmb}_{N}=\sum_{n=1}^{N}\left[\left\{\sum_{i=1}^{6}\left(I_{i n}-I_{i k}\right) / S_{i}\right\} / 6\right] / N
$$

$I_{\text {in }}$ - is the economic development score of the $i$ th item for the nth country;

$k$ - is Poland;

$S_{i}$ - stands for the standard deviation of the $i$ th score;

$N$ - is the number of countries in which the firm has foreign affiliates.

\section{Control variables}

For the Institutional Portfolio we computed the institutional development difference for each host country, using the World Governance Indicators for 2011-2012. We performed the same computation for cultural portfolio based on Hofstede's six cultural dimensions. Moreover, we controlled for Industry (equal to 1 for manufacturing, 0 for services, Brouthers, Brouthers, \& Werner, 2008); Firm Size (total years of FDI experience); Firm Age (years of operation); Firm Reputation (5-point Likert scale, where $1=$ we are much worse; $5=$ we are much better) how the perception and image of the MNE compare to those of their closest competitor).

\section{RESULTS AND DISCUSSION}

\section{Common method bias}

In order to avoid common method bias, the order of questions and items was varied so that no responses were suggested in the survey. The questions pertaining to the dependent variable were placed in the final part of the questionnaire. To test for common method bias, we conducted a post-hoc Harman's one-factor test (Podsakoff \& Organ, 1986). The unrotated principal component analysis showed four factors with eigenvalues greater than 1.0 , which collectively accounted for $66.6 \%$ of the total variance. The first and largest factor did account $24.1 \%$ of the variance.

\section{Descriptive statistics}

$64 \%$ of the sample are made up of companies operating in the manufacturing industry. $47 \%$ of the sampled firms have predominantly advanced economies in their FDI portfolios (i.e., FDI Economic Portfolio Composition is positive), giving sufficient variation to test our framework. The average multinational is about 25 years old with an average of 9 years of international experience on a range of 2 to 27.

Table 1 presents the variety of host countries in which the Polish new multinationals invest, and the total subsidiaries per host country in the sample. Overall, the FDI portfolios in the sample are quite heterogeneous: there are a total of 62 different host countries and 394 subsidiaries. The sam- 
ple is also dominated by European investments ( 45 European countries or $72 \%$, and 361 European subsidiaries or $92 \%$ ), in accordance with earlier studies of European multinationals (e.g., Dikova, 2009; Pollard \& Simberova, 2014).

Table 1. The FDI host countries and subsidiaries of the Polish new multinationals

\begin{tabular}{|c|c|c|c|}
\hline Host country of FDI & $\begin{array}{c}\text { Number of subsidiaries } \\
\text { per host country }\end{array}$ & Host country of FDI & $\begin{array}{l}\text { Number of subsidiar- } \\
\text { ies per host country }\end{array}$ \\
\hline Albania* & 2 & Macedonia* & 1 \\
\hline Argentina & 1 & Malaysia & 1 \\
\hline Armenia* & 1 & Moldova* & 3 \\
\hline Austria* & 7 & Montenegro* & 2 \\
\hline Azerbaijan* & 2 & Netherlands* & 2 \\
\hline Belarus* & 7 & Norway* & 4 \\
\hline Belgium* & 2 & Panama & 1 \\
\hline Bosnia \& Herzegovina* & 2 & Portugal* & 1 \\
\hline Brazil & 2 & Romania* & 30 \\
\hline Brunei Darussalam & 1 & Russia* & 30 \\
\hline Bulgaria* & 9 & Serbia* & 2 \\
\hline Canada & 2 & Singapore & 1 \\
\hline China & 7 & Slovakia* & 21 \\
\hline Croatia* & 3 & Slovenia* & 2 \\
\hline Czech Republic* & 40 & South Africa & 2 \\
\hline Denmark* & 6 & South Korea & 1 \\
\hline Estonia* & 2 & Spain* & 7 \\
\hline Finland* & 1 & Sweden* & 6 \\
\hline France* & 13 & Switzerland* & 4 \\
\hline Georgia & 1 & Tajikistan* & 1 \\
\hline Germany* & 42 & Tunisia & 1 \\
\hline Greece* & 1 & Turkey* & 6 \\
\hline Hungary* & 15 & Turkmenistan* & 1 \\
\hline Ireland* & 1 & Ukraine* & 33 \\
\hline Israel & 1 & United Arab Emirates & 2 \\
\hline Italy* & 8 & United Kingdom* & 15 \\
\hline Japan & 1 & United States of America & 7 \\
\hline Kazakhstan* & 5 & Uzbekistan* & 1 \\
\hline Kosovo* & 1 & Vietnam & 1 \\
\hline Kyrgyz Republic* & 1 & $\begin{array}{l}62 \\
\text { Host Countries }\end{array}$ & $\begin{array}{c}394 \\
\text { Subsidiaries }\end{array}$ \\
\hline Latvia* & 4 & \multirow{3}{*}{\multicolumn{2}{|c|}{ *indicates the European investments }} \\
\hline Lithuania* & 13 & & \\
\hline Luxembourg* & 1 & & \\
\hline
\end{tabular}

Source: survey data.

\section{Econometric findings}

Tables 2 and 3 present the descriptive statistics and correlations table. Table 5 show the findings of the different OLS regression models. The direct effect of Economic Portfolio was only marginally significant in Model 3B in Table 5 but non-significant in any other model. Thus, we did not find support for Hypothesis 1 in our sample. Yet, the interaction between the economic composition of the portfolios and the MNEs' capabilities was positive and significant in the full model (Model 2 in Table 5) as well as in the sub-group models of MNEs with high and low FDI experience (Models 3A and 3B in Table 4). This supports Hypothesis 2. Our findings suggest that locational ambidexterity should not be regarded as a capability in its own right but rather as a moderator for the remaining MNE capabilities. This moderating role is further highlighted by the marginal effects graph in Figure 2. For high levels of economic portfolios (dashed line in Figure 2), the effect of capabilities on MNE clearly exceeds the 
effect of the same level of capabilities of MNEs with low levels of economic portfolios (solid line in Figure 2). For low levels of capabilities, the graph shows reversed effects, emphasising the relevance of capabilities in FDI portfolios that require ambidexterity.

Table 2. Descriptive statistics

\begin{tabular}{|l|l|l|l|l|l|}
\hline \multicolumn{1}{|c|}{ Variables } & \multicolumn{1}{c|}{$\mathbf{N}$} & \multicolumn{1}{c|}{ Mean } & \multicolumn{1}{c|}{ Std. Dev. } & \multicolumn{1}{c|}{ Min } & \multicolumn{1}{c|}{ Max } \\
\hline MNE Overall Success & 100 & 3.282 & 0.743 & 1 & 5 \\
\hline FDI Experience & 100 & 9.380 & 4.947 & 2 & 27 \\
\hline MNE Reputation & 100 & 3.413 & 0.866 & 1 & 5 \\
\hline MNE Size & 100 & 6.346 & 1.654 & 2.995 & 10.434 \\
\hline MNE Age & 100 & 25.210 & 19.862 & 1 & 95 \\
\hline Industry & 100 & 0.610 & 0.490 & 0 & 1 \\
\hline Capabilities & 100 & 0.000 & 0.650 & -2.1922 & 1.474 \\
\hline Locational ambidexterity & 100 & 0.439 & 2.280 & -6.4394 & 9.776 \\
\hline Institutional Port. & 100 & -0.939 & 2.506 & -18.7136 & 2.803 \\
\hline Cultural Port. & 100 & 5.737 & 6.753 & 0.4950 & 34.312 \\
\hline
\end{tabular}

Source: own study.

Table 3. Correlations between key variables

\begin{tabular}{|c|l|c|c|c|c|c|c|c|c|c|c|}
\hline \multicolumn{2}{|c|}{ Variables (and their numbers) } & $(1)$ & $(2)$ & $(3)$ & $(4)$ & $(5)$ & $(6)$ & $(7)$ & $(8)$ & $(9)$ & $(10)$ \\
\hline$(1)$ & MNE Overall Success & 1 & & & & & & & & & \\
\hline$(2)$ & FDI Experience & 0.12 & 1 & & & & & & & \\
\hline$(3)$ & MNE Reputation & $\begin{array}{c}0.35 \\
* * *\end{array}$ & 0.11 & 1 & & & & & & & \\
\hline$(4)$ & MNE Size & 0.09 & $\begin{array}{c}0.31 \\
* * *\end{array}$ & 0.01 & 1 & & & & & & \\
\hline$(5)$ & MNE Age & -0.03 & $0.19 *$ & 0.01 & $\begin{array}{c}0.38 \\
* * *\end{array}$ & 1 & & & & & \\
\hline$(6)$ & Industry & 0.05 & $\begin{array}{c}0.27 \\
* * *\end{array}$ & -0.02 & $\begin{array}{c}0.28 \\
* * *\end{array}$ & $\begin{array}{c}0.19 \\
*\end{array}$ & 1 & & & & \\
\hline$(7)$ & Capabilities & $\begin{array}{c}0.55 \\
* * *\end{array}$ & 0.09 & $\begin{array}{c}0.38 \\
* * *\end{array}$ & $\begin{array}{c}-0.02 \\
0.11\end{array}$ & 0.09 & 1 & & & \\
\hline$(8)$ & Locational ambidexterity & 0.00 & -0.01 & -0.07 & -0.14 & -0.13 & -0.03 & -0.05 & 1 & & \\
\hline$(9)$ & Institutional Port. & -0.10 & $\begin{array}{c}-0.22 \\
* *\end{array}$ & -0.06 & $\begin{array}{c}-0.23 \\
* *\end{array}$ & $\begin{array}{c}-0.25 \\
* *\end{array}$ & -0.09 & -0.05 & $\begin{array}{c}0.51 \\
* * *\end{array}$ & 1 \\
\hline$(10)$ & Cultural Port. & 0.16 & $\begin{array}{c}0.32 \\
* * *\end{array}$ & 0.11 & $\begin{array}{c}0.38 \\
* * *\end{array}$ & 0.07 & 0.03 & -0.15 & 0.09 & $\begin{array}{c}-0.38 \\
* * *\end{array}$ & 1 \\
\hline
\end{tabular}

Notes: ${ }^{* * *}: p<0.01 ;{ }^{* *}: p<0.05 ;{ }^{*}: p<0.1$

Source: own study.

Jointly, our findings regarding the first two hypotheses provide some additional insights on the mechanisms how locational ambidexterity affects firm performance. While our data confirm that MNEs pursue an international expansion combining exploration and exploitation, or ambidexterity (Raisch \& Birkinshaw, 2008), the lack of significant direct effects of locational ambidexterity differs from previous findings such as Kim, Hoskisson and Lee (2015) or Makino, Lau and Yeh (2002). Moreover, our results reinforce previous studies which identified resources and capabilities as crucial prerequisites for successful locational ambidexterity (Kim, Mahoney, \& Tan, 2015). In particular, we contribute to previous research by shedding light on the role of experience in managing various, often contradictory, international commitments within a firm's portfolio. This finding strengthens the role the resource-based-view plays in internationalisation processes towards different institutional contexts (Brouthers, Brouthers, \& Werner, 2008). 


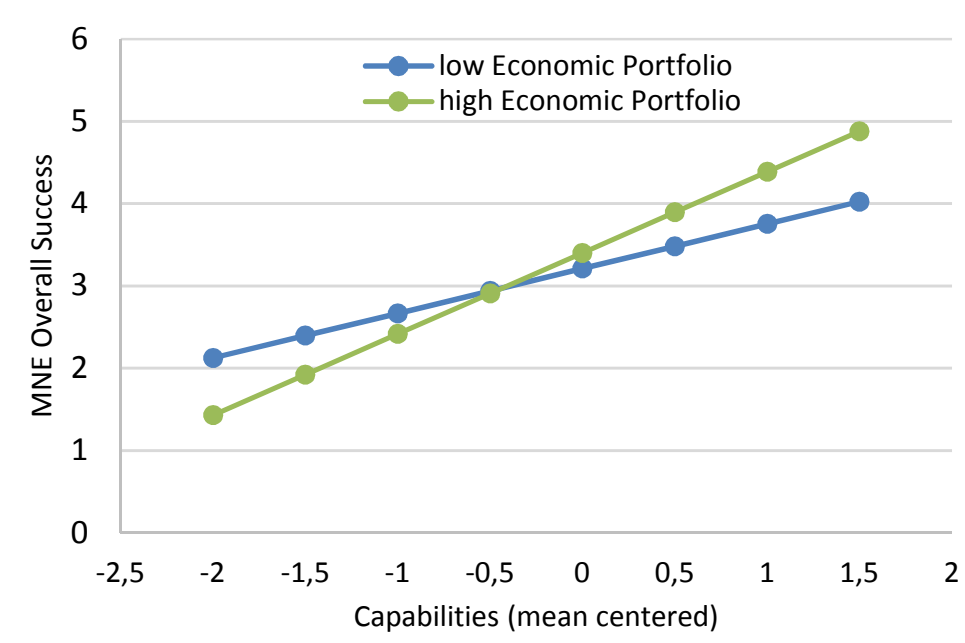

Figure 2. Marginal effects graph Source: own elaboration.

Table 4. Regression models (MNE performance)

\begin{tabular}{|c|c|c|c|c|c|c|c|}
\hline Variable & Base model & Model 1 & Model 2 & $\begin{array}{r}\text { Model } \\
\text { (high Ex }\end{array}$ & & $\begin{array}{r}\text { Mode } \\
\text { (low Ext }\end{array}$ & \\
\hline Constant & $\begin{array}{l}2.535^{* * *} \\
(0.3600)\end{array}$ & $\begin{array}{l}2.758^{* * *} \\
(0.378)\end{array}$ & $\begin{array}{l}2.793 * * * \\
(0.369)\end{array}$ & $\begin{array}{l}3.475 \\
(.599)\end{array}$ & $* * *$ & $\begin{array}{l}2.169 \\
(0.682)\end{array}$ & $* * *$ \\
\hline FDI Experience & $\begin{array}{r}0.007 \\
(0.014)\end{array}$ & $\begin{array}{l}-0.002 \\
(0.014)\end{array}$ & $\begin{array}{l}-0.008 \\
(0.014)\end{array}$ & $\begin{array}{l}0.001 \\
(0.022)\end{array}$ & & $\begin{array}{l}-0.006 \\
(.046)\end{array}$ & \\
\hline MNE Reputation & $\begin{array}{r}0.129 \\
(0.078) \\
\end{array}$ & $\begin{array}{r}0.099 \\
(0.079) \\
\end{array}$ & $\begin{array}{r}0.116 \\
(0.077) \\
\end{array}$ & $\begin{array}{l}0.075 \\
(0.093)\end{array}$ & & $\begin{array}{l}.210 \\
(.131)\end{array}$ & \\
\hline MNE Size & $\begin{array}{r}0.063 \\
(0.043)\end{array}$ & $\begin{array}{r}0.029 \\
(0.046)\end{array}$ & $\begin{array}{l}0.015 \\
(.045)\end{array}$ & $\begin{array}{l}-0.045 \\
(0.067)\end{array}$ & & $\begin{array}{l}.042 \\
(.066)\end{array}$ & \\
\hline MNE Age & $\begin{array}{l}-0.005 \\
(0.003)\end{array}$ & $\begin{array}{r}-0.005 \\
(0.003)\end{array}$ & $\begin{array}{l}-0.004 \\
(0.003)\end{array}$ & $\begin{array}{l}-0.004 \\
(0.005)\end{array}$ & & $\begin{array}{l}-0.005 \\
(0.005)\end{array}$ & \\
\hline Capabilities & $\begin{array}{l}0.5811^{* * *} \\
(0.105)\end{array}$ & $\begin{array}{l}0.634^{* * *} \\
(0.106)\end{array}$ & $\begin{array}{l}0.668^{* * *} \\
(0.105)^{4}\end{array}$ & $\begin{array}{l}0.827 \\
0.129)\end{array}$ & $* * *$ & $\begin{array}{l}0.599 \\
(0.182)\end{array}$ & $* * *$ \\
\hline $\begin{array}{l}\text { Locational ambidex- } \\
\text { terity }\end{array}$ & & $\begin{array}{c}0.004 \\
(0.034)\end{array}$ & $\begin{array}{c}0.036 \\
(0.036)\end{array}$ & $\begin{array}{l}-0.021 \\
(0.039)\end{array}$ & & $\begin{array}{l}0.138 \\
(0.091)\end{array}$ & $*$ \\
\hline $\begin{array}{l}\text { Locational ambidex- } \\
\text { terity } \times \text { Capab. }\end{array}$ & & & $\begin{array}{l}0.082 * * \\
(0.036)\end{array}$ & $\begin{array}{l}0.068 \\
(0.034)\end{array}$ & $*$ & $\begin{array}{l}0.240 \\
(0.145)\end{array}$ & \\
\hline Institutional Port. & & $\begin{array}{r}-0.001 \\
(0.034) \\
\end{array}$ & $\begin{array}{r}-0.036 \\
(0.036) \\
\end{array}$ & $\begin{array}{l}0.004 \\
(0.036)\end{array}$ & & \begin{tabular}{|l|}
-0.142 \\
$(0.096)$ \\
\end{tabular} & \\
\hline Cultural Port. & & $\begin{array}{l}0.024^{* *} \\
(0.012)\end{array}$ & $\begin{array}{c}0.021 * \\
(0.012)\end{array}$ & $\begin{array}{l}0.030 \\
(0.012) \\
\end{array}$ & $* *$ & $\begin{array}{l}0.046 \\
(0.036)\end{array}$ & \\
\hline $\begin{array}{l}\text { Industry } \\
\text { Dummy }\end{array}$ & yes & yes & yes & yes & & yes & \\
\hline $\mathrm{N}$ & 100 & 100 & 100 & 43 & & 57 & \\
\hline Prob. F-test & $0.000 * * *$ & $0.000 * * *$ & $0.000 * * *$ & 0.000 & $* * *$ & 0.018 & $* *$ \\
\hline Adj.R2 & 0.312 & 0.329 & 0.359 & 0.539 & & 0.211 & \\
\hline
\end{tabular}

Notes: ${ }^{* * *}: \mathrm{p}<0.01 ;{ }^{* *}: \mathrm{p}<0.05 ;{ }^{*}: \mathrm{p}<0.1$

Source: own study.

In Hypothesis 3, we argued that the enhancing effect of locational ambidexterity on the performance impact of superior capabilities is stronger for new MNEs with a higher portfolio management experience. To test Hypothesis 3, we split our sample of new MNEs into more experienced MNEs (above average number of years of experience with FDI) and less experienced MNEs (below average number of years of 
experience with FDI). For more experienced MNEs we found a significant result (Model $3 \mathrm{~A}$ in Table 4) whereas the result for less experienced MNEs is only marginally significant (Model 3B in Table 4). Thus, the findings of Models $3 \mathrm{~A}$ and $3 \mathrm{~B}$ support Hypothesis 3 . These findings highlight the complexity of managing locational ambidexterity. Unexperienced new MNEs lack the competence to pursue a dual strategy and might be better advised to gain experience with a focus on either exploitation or exploration (Luo \& Tung, 2007). Enhanced FDI experience, nevertheless, enables new MNEs to exploit their capabilities in more complex country portfolios (Trąpczyński \& Banalieva, 2016).

\section{CONCLUSIONS}

The added value of our study is that it enhances earlier studies devoted to FDI location choices of multinationals from developed markets (Galan, González-Benito, \& Zuñga-Vincente, 2007; Kumar, 2001), newly industrialised countries (Makino, Lau, \& Yeh, 2002), or traditional emerging markets like China (Ramaswamy, Yeung, \& Laforet, 2012). Conversely, the knowledge about the location choices of new multinationals from mid-range economies has still remained limited. New multinationals' choices about the level of market sophistication in their FDI portfolios differs from the FDI choices other multinationals make due to the different level of factor market development conditions in their home countries (Hoskisson et al., 2013; Kim, Hoskisson, \& Lee, 2015).

Our study advanced two key theoretical contributions. First, few studies have adopted an integrative portfolio perspective on geographic portfolio choices, and have instead focused on discrete FDI location choices at a point in time (Nielsen, Asmussen, \& Weatherall, 2017). Equally few studies have consistently considered location choices from the point of view of broader corporate strategy, linking location choices to other strategic decisions like, e.g., building intangible resources. Second, while earlier research has conceptualised entry into advanced countries and emerging markets as two mutually exclusive strategic choices, we proposed instead that firms can pursue both at the same time. We believe this approach reflects a more realistic representation of the complex optimisation decisions new multinationals make with respect to the level of market sophistication in their FDI portfolios that has evaded prior research.

Further, there is no direct performance effect of adding more advanced markets to the portfolio, as this relationship depends on the possessed capabilities. Thus, we caution new MNE managers that chasing after the glamour of advanced host countries is a double-edged sword: it can significantly improve firms' intangible resource base, but also significantly hurt performance, at least in the short term. Managers of new multinationals should carefully balance their exploration-exploitation activities so as to reduce the negative effect on performance.

Our research is obviously limited in a number of aspects which nevertheless pose fruitful areas for further efforts. First, consistent with prior quantitative studies on companies' internationalisation (e.g., Carlsson, Nordegren, \& Sjoholm, 2005; Hernandez \& Nieto, 2015; Liu, Gao, Lu, \& Lioliou, 2016), our study relies on a survey-based cross-sectional sample of FDI portfolios. Thus, we were not able to perform panel data regression analysis to test for possible longitudinal shifts in the new multinationals' FDI strategies over time. Thus, future research can test the generalisability of our findings on longer time frames as more data become publicly available. Second, future research can expand ours by analysing larger firm samples. Since we were only able to capture short-term performance, it would be useful for upcoming studies to expand our work by analysing the long-term performance implications from the FDI portfolio optimisation of new multinationals. Third, despite the notable heterogeneity of host country locations in the Polish firms' FDI portfolios (62 countries, 394 subsidiaries), most FDI in the sample was in Europe, hence further research could recur to larger and more diversified portfolios which would help to corroborate our findings. 


\section{REFERENCES}

Anand, J., Mesquita, L.F., \& Vassolo, R.S. (2009). The dynamics of multimarket competition in exploration and exploitation activities. Academy of Management Journal, 52(4), 802-821. https://doi.org/10.5465/amj.2009.43670897

Armstrong, J., \& Overton, T. (1977). Estimating nonresponse bias in mail surveys. Journal of Marketing Research, 14, 396-402. https://doi.org/10.1177/002224377701400320

Asgari, N., Singh, K., \& Mitchell, W. (2017). Alliance portfolio reconfiguration following a technological discontinuity. Strategic Management Journal, 38(5), 1062-1081. https://doi.org/10.1002/smj.2554

Banalieva, E., \& Dhanaraj, C. (2013). Home-region orientation in international expansion strategies. Journal of International Business Studies, 44(2), 89-116. https://doi.org/10.1057/jibs.2012.33

Barłożewski, K., \& Trąpczyński, P. (2021a). Internationalisation motives and the multinationality-performance relationship: The case of Polish firms. Entrepreneurial Business and Economics Review, 9(2), 85-104. https://doi.org/10.15678/EBER.2021.090206

Barłożewski, K., \& Trąpczyński, P. (2021b). Is internationalisation beneficial for novice internationalisers? The performance effects of firm-specific advantages, internationalisation degree and firm size revisited. Oeconomia Copernicana, 12(1), 53-75. https://doi.org/10.24136/oc.2021.003

Benner, M.J., \& Tushman, M.L. (2003). Exploitation, exploration, and process management: The productivity dilemma revisited. Academy of Management Review, 28(2), 238-256. https://doi.org/10.2307/30040711

Bilan, Y., Mishchuk, H., Samoliuk, N., \& Mishchuk, V. (2020). Gender discrimination and its links with compensations and benefits practices in enterprises. Entrepreneurial Business and Economics Review, 8(3), 189-204. https://doi.org/10.15678/EBER.2020.080311

Braja, M., \& Gemzik-Salwach, A. (2020). Competitiveness of high-tech exports in the EU countries. Journal of International Studies, 13(1), 359-372. doi:10.14254/2071-8330.2020/13-1/23

Brouthers, K.D., Brouthers, L.E., \& Werner, S. (2008). Resource-based advantages in an international context?. Journal of Management, 34, 189-217. https://doi.org/10.1177/0149206307312508

Brouthers, L.E., Nakos, G., Hadjimarcou, J., \& Brouthers, K.D. (2009). Key factors for successful export performance for small firms. Journal of International Marketing, 17(3), 21-38. https://doi.org/10.1509/jimk.17.3.21

Carlsson, J., Nordegren, A., \& Sjoholm, F. (2005). International experience and the performance of Scandinavian firms in China. International Business Review, 14, 21-40. https://doi.org/10.1016/j.ibusrev.2004.10.003

Chacar, A., Newburry, B., \& Vissa, B. (2010). Bringing institutions into performance persistence research: exploring the impact of product, financial, and labor market institutions. Journal of International Business Studies, 41, 1119-1140. https://doi.org/10.1057/jibs.2010.3

Chan, C., Isobe, T., \& Makino S. (2008). Which country matters? Institutional development and foreign affiliate performance. Strategic Management Journal, 29, 1179-1205. https://doi.org/10.1002/smj.705

Cieślik, A., \& Hien Tran, G. (2019). Determinants of outward FDI from emerging economies. Equilibrium. Quarterly Journal of Economics and Economic Policy, 14(2), 209-231. https://doi.org/10.24136/eq.2019.010.

Cieślik, A., Michałek, J. J., \& Szczygielski, K. (2019). What matters for firms? participation in Global Value Chains in Central and East European countries?. Equilibrium. Quarterly Journal of Economics and Economic Policy, 14(3), 481-502. https://doi.org/10.24136/eq.2019.023.

Cuervo-Cazurra, A., \& Genc, M. (2008). Transforming disadvantages into advantages: developing-country MNEs in the least developed countries. Journal of International Business Studies, 39, 957-979. https://doi.org/10.1057/palgrave.jibs.8400390

Crescenzi, R., Pietrobelli, C., \& Rabellotti, R. (2015). Location strategies of multinationals from emerging countries in the EU regions. LEQS Paper, 93. Retrieved from http://aei.pitt.edu/93655/1/LEQSPaper93.pdf on April 22, 2021.

Del Sol, P., \& Kogan, J. (2007). Regional competitive advantage based on pioneering economic reforms: The case of Chilean FDI. Journal of International Business Studies, 38(6), 901-927. https://doi.org/10.1057/palgrave.jibs. 8400299

Demirbag, M., Glaister, K.W., \& Tatoglu, E. (2007). Institutional and transaction cost influences on MNEs' ownership strategies of their affiliates: Evidence from an emerging market. Journal of World Business, 42(4), 418434. https://doi.org/10.1007/s 11575-010-0055-y 
Dikova, D. (2009). Performance of foreign subsidiaries: does psychic distance matter?. International Business Review, 18, 38-49. https://doi.org/10.1016/j.ibusrev.2008.11.001

Dunning, J. (1988). The eclectic paradigm of international production: a restatement and some possible extensions. Journal of International Business Studies, 19(1), 1-31. https://doi.org/10.1057/palgrave.jibs.8490372

Galan, J., González-Benito, J., \& Zuñga-Vincente, J. (2007). Factors determining the location decisions of Spanish MNEs: an analysis based on the investment development path. Journal of International Business Studies, 38(6), 975-997. https://doi.org/10.1057/palgrave.jibs.8400304

García-Canal, E., Guillén, M.F., Fernández, P., \& Puig, N. (2018). Imprinting and early exposure to developed international markets: The case of the new multinationals. BRQ Business Research Quarterly, 21(3), 141-152. https://doi.org/10.1016/j.brq.2018.05.001

Głodowska, A., Pera, B., \& Wach, K. (2019). International strategy as the facilitator of the speed, scope, and scale of firms' internationalization. Central European Management Journal, 27(3), 55-84. https://doi.org/10.7206/cemj.2658-0845.3

Guillen, M., \& Garcia-Canal, E. (2009). The American model of the multinational firm and the "new" multinationals from emerging markets. Academy of Management Perspectives, 23-35. https://doi.org/10.5465/amp.2009.39985538

Gupta, A.K., Smith, K.G., \& Shalley, C.E. (2006). The interplay between exploration and exploitation. Academy of Management Journal, 49(4), 693-706. https://doi.org/10.5465/amj.2006.22083026

Hamzaoui, L., \& Merunka, D. (2006). The impact of country of design and country of manufacture on consumer perceptions of bi-national products' quality: an empirical model based on the concept of fit. Journal of Consumer Marketing, 23(3), 145-155. https://doi.org/10.1108/07363760610663303

He, Z., \& Wong, P. (2004). Exploration vs. exploitation: An empirical test of the ambidexterity hypothesis. Organization Science, 15(4), 481-494. https://doi.org/10.1287/orsc.1040.0078

Hennart, J.-F. (2012). Emerging market multinationals and the theory of the multinational enterprise. Global Strategy Journal, 2(3), 168-187. https://doi.org/10.1111/j.2042-5805.2012.01038.x

Hernandez, V., \& Nieto, M. (2015). The effect of the magnitude and direction of institutional distance on the choice of international entry modes. Journal of World Business, 50(1), 122-132. https://doi.org/10.1016/j.jwb.2014.02.002

Hernandez, E., \& Guillén, M.F. (2018). What's theoretically novel about emerging-market multinationals?. Journal of International Business Studies, 49(1), 24-33. https://doi.org/10.1057/s41267-017-0131-7

Hoskisson, R., Wright, M., Filatotchev, I., \& Peng, M. (2013). Emerging multinationals from mid-range economies: the influence of institutions and factor markets. Journal of Management Studies, 50(7), 1295-1321. https://doi.org/10.1111/j.1467-6486.2012.01085.x

Hymer, S. (1976). The International Operations of National Firms: A Study of Direct Foreign Investment. Cambridge, Massachussets: MIT Press.

Khan, H. (2020). Is marketing agility important for emerging market firms in advanced markets?. International Business Review, 29(5), 101733. https://doi.org/10.1016/j.ibusrev.2020.101733

Kim, H., Hoskisson, R., \& Lee, S. (2015). Why strategic factor markets matter: “New” multinationals' geographic diversification and firm profitability. Strategic Management Journal, 36(4), 518-536. https://doi.org/10.1002/smj.2229

Kim, M., Mahoney, J., \& Tan, D. (2015). Re-conceptualising exploitative and explorative FDI: a balancing-process approach to firm internationalisation. European Journal of International Management, 9(5), 537-565. https://doi.org/10.1504/EJIM.2015.071513

Kogut, B., \& Singh, H. (1988). The effect of national culture on the choice of entry mode. Journal of International Business Studies 19(3), 411-432. https://doi.org/10.1057/palgrave.jibs.8490394

Kohli, A.K., \& Jaworski, B.J. (1990). Market orientation: the construct, research propositions, and managerial implications. Journal of Marketing, 54, 1-18. https://doi.org/10.1177/002224299005400201

Kriauciunas, A., Parmigiani, A., \& Rivera-Santos, M. (2011). Leaving our comfort zone: integrating established practices with unique adaptations to conduct survey-based strategy research in nontraditional contexts. Strategic Management Journal, 32, 994-1010. https://doi.org/10.1002/smj.921

Kumar, N. (2001). Determinants of location of overseas R\&D activity of multinational enterprises: The case of US and Japanese corporations. Research Policy 30(1), 159-174. https://doi.org/10.1016/S0048-7333(99)00102-X 
Kumar, V., Singh, D., Purkayastha, A., Popli, M., \& Gaur, A. (2020). Springboard internationalization by emerging market firms: Speed of first cross-border acquisition. Journal of International Business Studies, 51(2), 172193. https://doi.org/10.1057/s41267-019-00266-0

Lavie, D., \& Rosenkopf, L. (2006). Balancing exploration and exploitation in alliance formation. Academy of Management Journal, 49(4), 797-818. https://doi.org/10.5465/amj.2006.22083085

Lee, C. W., \& Fernando, A. (2020). Can internally generated FDI impact export performance? The study on Indonesia in the years 1980-2018. International Entrepreneurship Review, 6(1), 29-45. https://doi.org/10.15678/IER.2020.0601.02

Levinthal, D.A., \& March, J.G. (1993). The myopia of learning. Strategic Management Journal, 14(S2), 95-112. https://doi.org/10.1002/smj.4250141009

Liu, X., Gao, L., Lu, J., \& Lioliou, E. (2016). Does learning at home and from abroad boost the foreign subsidiary performance of emerging economy multinational enterprises?. International Business Review, 25(1A), 141151. https://doi.org/10.1016/j.ibusrev.2014.10.012

Li, L. (2007). Multinationality and performance: A synthetic review and research agenda. International Journal of Management Reviews, 9(2), 117-139. https://doi.org/10.1111/j.1468-2370.2007.00205.x

Luo, Y., \& Tung, R.L. (2007). International expansion of emerging market enterprises: A springboard perspective. Journal of International Business Studies, 38, 481-498. https://doi.org/0.1057/palgrave.jibs.8400275

Maciejewski, M., \& Wach, K. (2019). International Startups from Poland: Born Global or Born Regional?. Journal of Management and Business Administration Central Europe, 27(1), 60-83. https://doi.org/10.7206/jmba.ce.2450-7814.247

Makino, S., Lau, C., \& Yeh, R. (2002). Asset-expoitation versus asset-seeking: implications for location choice of foreign direct investment from newly industrialized economies. Journal of International Business Studies, 38, 481-498. https://doi.org/10.1057/palgrave.jibs.8491024

March, J. (1991). Exploration and exploitation in organizational learning. Organization Science, 2(1), 71-87. https://doi.org/10.1287/ORSC.2.1.71

Mayer, T., \& Zignano, S. (2005). Notes on CEPII's distances measures: The GeoDist database. CEPII, WP No 2011 - 25. Retrieved from http://www.cepii.fr/PDF_PUB/wp/2011/wp2011-25.pdf on April 22, 2021.

McMillan, J., \& Woodruff, C. (2002). The central role of entrepreneurs in transitional economies. Journal of Economic Perspectives, 16(3), 153-170. https://doi.org/10.1257/089533002760278767

Miller, K.D., Zhao, M., \& Calantone, R.J. (2006). Adding interpersonal learning and tacit knowledge to March's exploration-exploitation model. Academy of Management Journal, 49(4), $709-722$. https://doi.org/10.5465/amj.2006.22083027

Mishchuk, H., Bilan, S., Yurchyk, H., Akimova, L., \& Navickas, M. (2020). Impact of the shadow economy on social safety: The experience of Ukraine. Economics and Sociology, 13(2), 284-298.doi:10.14254/2071789X.2020/13-2/19

Nielsen, B., Asmussen, C., \& Weatherall, C. (2017). The location choice of foreign direct investments: empirical evidence and methodological challenges. Journal of World Business, 52, 62-82. https://doi.org/10.1016/j.jwb.2016.10.006

Ozmel, U., \& Guler, I. (2015). Small fish, big fish: The performance effects of the relative standing in partners' affiliate portfolios. Strategic Management Journal, 36(13), 2039-2057. https://doi.org/10.1002/smj.2332

Padmanabhan, P., \& Cho, K. (1999). Decision specific experience in foreign ownership and establishment strategies: Evidence from Japanese firms. Journal of International Business Studies, 30(1), 25-41. https://doi.org/10.1057/palgrave.jibs.8490059

Paliokaite, A. (2019). An innovation policy framework for upgrading firm absorptive capacities in the context of catching-up economies. Journal of Entrepreneurship, Management and Innovation, 15(3), 103-130. https://doi.org/10.7341/20191534

Pattnaik, C., Choe, S., \& Singh, D. (2015). Impact of host country institutional context on subsidiary performance. Management Decision, 53(1), 198-220. https://doi.org/10.1108/MD-08-2014-0514

Perkins, S.E. (2014). When does prior experience pay? Institutional experience and the multinational corporation. Administrative Science Quarterly, 59(1), 145-181. https://doi.org/10.2139/ssrn.1088251

Podsakoff, P., \& Organ, D. (1986). Self-reports in organizational research: problems and prospects. Journal of Management, 12(4), 531-544. https://doi.org/10.1177/014920638601200408 
Pollard, D., \& Simberova, I. (2014). The internationalization of SMEs in the Czech Republic: strategic and knowledge development issues. In E. Turkina, \& M.T.T. Thai (Eds.), Internationalization of firms from economies in-transition: the effects of politico-economic paradigm shift (pp. 90-108). Cheltenham: Edward Elgar Publishing.

Polowczyk, J., Zaks, O., \& Trąpczyński, P. (2021). On the role of communication and management engagement for acquisition success: A Study of Israeli Start-Ups. International Entrepreneurship Review, 7(4).

Raisch, S., \& Birkinshaw, J. (2008). Organizational ambidexterity: Antecedents, outcomes, and moderators. Journal of Management, 34(3), 375-409. https://doi.org/10.1177/0149206308316058

Ramamurti, R. (2012). What is really different about emerging market multinationals?. Global Strategy Journal, 2, 41-47. https://doi.org/10.1002/gsj.1025

Ramaswamy, B., Yeung, M., \& Laforet, S. (2012). China's outward foreign direct investment: location choice and firm ownership. Journal of World Business, 47(1), 17-25. https://doi.org/10.1016/j.jwb.2010.10.016

Rivkin, J., \& Siggelkow, N. (2003). Balancing search and stability: Interdependencies among elements of organizational design. Management Science, 49(3), 290-311. https://doi.org/10.1287/mnsc.49.3.290.12740

Rudawska, E., Frąckiewicz, E., \& Wiścicka-Fernando, M. (2018). Socio-ecological innovations in marketing strategy - a comparative analysis of companies operating in Western European countries and Central-Eastern European countries. Economics and Business Review, 18(3), 51-68. https://doi.org/10.18559/ebr.2018.3.5

Rugman, A.M., \& Verbeke, A. (2001). Subsidiary-specific advantages in multinational enterprises. Strategic Management Journal, 22(3), 237-250. https://doi.org/10.1002/smj.153

Siggelkow, N., \& Rivkin, J. (2006). When exploration backfires: unintended consequences of multilevel organizational search. Academy of Management Journal, 49(4), 779-795. https://doi.org/10.5465/amj.2006.22083053

Sousa, C., Ruzo, E., \& Losada, F. (2010). The key role of managers' values in exporting: influence on customer responsiveness and export performance. Journal of International Marketing, 18(2), 1-19. https://doi.org/10.1509/jimk.18.2.1

Stjepić, A.M., Ivančić, L., \& Suša Vugec, D. (2020). Mastering digital transformation through business process management: Investigating alignments, goals, orchestration, and roles. Journal of Entrepreneurship, Management and Innovation, 16(1), 41-74. https://doi.org/10.7341/20201612

Thomas, D.E., Eden, L., Hitt, M.A., \& Miller, S.R. (2007). Experience of emerging market firms: The role of cognitive bias in developed market entry and survival. Management International Review, 47(6), 845-867. https://doi.org/10.1007/s11575-007-0055-8

Trąpczyński, P., \& Banalieva, E.R. (2016). Institutional difference, organizational learning, and foreign affiliate performance: Evidence from Polish firms. Journal of World Business, 51(5), 826-842. https://doi.org/10.1016/j.jwb.2016.07.013

Tsang, E., \& Yip, P. (2007). Economic distance and the survival of foreign direct investments. Academy of Management Journal, 50(5), 1156-1168. https://doi.org/10.2307/20159917

Verbeke, A., \& Brugman, P. (2009). Triple-testing the quality of multinationality-performance research: An internalization theory perspective. International Business Review, 18(3), 265-275. https://doi.org/10.1016/j.ibusrev.2009.01.005

Verbeke, A., Li, L., \& Goerzen, A. (2009). Toward more effective research on the multinationality-performance relationship. Management International Review, 49(2), 149-161. https://doi.org/10.1007/s11575-008-0133-6

Wu, J., \& Ang, S.H. (2020). Network complementaries in the international expansion of emerging market firms. Journal of World Business, 55(2), 101045. https://doi.org/10.1016/j.jwb.2019.101045

Yang, Y., Martins, P.S., \& Driffield, N. (2013). Multinational performance and the geography of FDI. Management International Review, 53(6), 763-794. https://doi.org/10.1007/s11575-013-0180-5

Zaheer, S. (1995). Overcoming the liability of foreignness. Academy of Management Journal, 38(2), 341-363. https://doi.org/10.2307/256683

Zahra, S.A., Ireland, R.D., \& Hitt, M.A. (2000). International expansion by new venture firms: International diversity, mode of market entry, technological learning, and performance. Academy of Management Journal, 43(5), 925-950. https://doi.org/10.2307/1556420 


\section{Authors}

The contribution share of authors is equal and amounted to $50 \%$ for each of them.

\section{Piotr Trąpczyński}

Associate Professor at the Poznań University of Economics and Business, Department of International Competitiveness at the Institute of International Business and Economics. His research interests include foreign direct investments and divestments, export performance and export exits, along with business models.

Correspondence to: Dr hab. Piotr Trąpczyński, prof. UEP, Department of International Competitiveness, Poznań University of Economics and Business, al. Niepodległości 1, 61-875 Poznań, Poland, e-mail: piotr.trapczynski@ue.poznan.pl

ORCID i http://orcid.org/0000-0001-8154-9174

\section{Tilo Halaszovich}

Professor of Global Markets and Firms at the Jacobs University Bremen, Germany. His research is mostly focused on quantitative analysis in entrepreneurship and international business. He is especially interested in the competitiveness of foreign and domestic firms in developing countries.

Correspondence to: Prof. Dr. Tilo Halaszovich, Jacobs University Bremen, Business Studies \& Economics, Campus Ring 1, Research IV, 28759 Bremen, Germany, e-mail: t.halaszovich@jacobs-university.de ORCID (1) http://orcid.org/0000-0003-2182-0879

\section{Acknowledgements and Financial Disclosure}

The authors would like to thank Charles Dhanaraj and Elitsa R. Banalieva for their cooperation on earlier concepts which preceded this paper. This study has been financed by the research grant of the Polish Science Centre, awarded based on the decision no. DEC-2012/07/N/HS4/00283.

\section{Conflict of Interest}

The authors declare that the research was conducted in the absence of any commercial or financial relationships that could be construed as a potential conflict of interest.

\section{Copyright and License}

This article is published under the terms of the Creative Commons

Attribution - NoDerivs (CC BY-ND 4.0) License

http://creativecommons.org/licenses/by-nd/4.0/ 
